\title{
Investigating the Effects of Price and Brand Leveraging Strategy on Consumer's Behavioral Intention (Case Study: Daily Food Products)
}

\author{
Seyed Fathollah Amiri Aghdaie ${ }^{1}$, Hossein Rezaei Dolatabadi ${ }^{1} \&$ Maryam Adibparsa $^{1}$ \\ ${ }^{1}$ Department of Management, University of Isfahan, Isfahan, Iran \\ Correspondence: Seyed Fathollah Amiri Aghdaie, Department of Management, University of Isfahan, HezarJerib, \\ St. Darvazeh Shiraz, Isfahan, Iran. Tel: 98-311-793-5251. E-mail: s.aghdaie@ase.ui.ac.ir
}

Received: July 31, 2012 Accepted: September 25, 2012 Online Published: October 22, 2012

doi:10.5539/ijbm.v7n22p76 URL: http://dx.doi.org/10.5539/ijbm.v7n22p76

\begin{abstract}
Marketers often use a credible and familiar brand name on their products to highlight the unobservable quality and important attributes of the products. Drawing on signaling theory, brand leveraging strategy is the presence of credible and familiar brand along with the primary brand on the product. Conceptualizing from the co-branding literature, brand leveraging strategy enhances consumer's evaluations of product quality, perceptions of value and their willingness to buy. This study examines how the effects of price and combining two brand names influence consumer's evaluation of a product. The study findings offer empirical evidence that applying of brand leveraging strategy results in higher perceived quality. Product cues such as (brand names and price) must be positively consistent to gain the highest perceived quality from consumers. This study provides some important implications for marketers attempting to implement brand leveraging strategy, and for consumers to understand the presence of a credible and familiar brand name as signal of an unobservable product quality and important attributes.
\end{abstract}

Keywords: signaling theory, the price-quality-value model, brand leveraging, price, daily food industry

\section{Introduction}

The focus of this study concerns issues related to introducing to the market a new line of products and the alternative branding strategies it might use. In this situation, an important issue is how to obtain market acceptance of the new product such that it is a success. Given the newness of the products, potential consumers may be uncertain as to the quality of the offering and its ability to provide the benefits they seek. Since consumers are inherently skeptical, sellers of new products have used a variety of strategies and tactics to overcome the inertia caused by consumers' uncertainties. Utilization of a credible and familiar brand name on a product package is one possible marketing strategy that conveys additional information on product attributes and product quality to consumers.

Recent research based on the economics of information and signaling theory has studied ways for sellers to convince consumers that a new product is as good as they claim (Kirmani and Rao, 2000; Rao and Ruekert, 1994). When consumers are uncertain as to the quality of an offering, sellers can provide cues or signals that are credible and, therefore, capable of conveying information to consumers about the product's quality and performance capability. Such cues include setting a relatively high price, offering a temporary introductory low price to induce trial, heavy advertising expenditures, providing a warranty or money-back guarantee, using a third party verification of product quality from a credible certification agency or using a credible and familiar brand name with the primary brand. The focus of this research is on another cues that are also strategic decisions for sellers, the branding decision and setting price.

\section{Signaling Theory}

One theoretical foundation for this research comes from the economics of information and signaling theory. When consumers are uncertain about the quality of products, sellers may use brand names to position the products in markets and to give credibility to the quality claims made.

Brands as signals improve consumers' perceptions about brand attribute levels and their confidence in the credibility of the firm's quality claims. This reduced uncertainty lowers consumers' information costs and perceived risk, thereby enhancing perceptions of value (Urbany et al., 1996). The value of a brand has been 
referred to as customer-based brand equity (Keller, 2003). Customer-based brand equity refers to the effect that customers' brand knowledge has on their response to the marketing of the brand. If customers react favorably to a product and the way it is marketed when the brand is identified compared to when it is not, then the brand is said to have positive customer-based brand equity.

Research on signaling theory has considered a variety of signals including price, brand, advertising expenditures, and warranties (Kirmani and Rao, 2000; Monroe, 2003). A product's brand name is a cue for customers representing images that they have formed given their experiences with the brand and the information they have acquired about the brand. Familiar brands with which customers have a favorable image are signals that induce trust and confidence that the product will provide the level of benefits expected; that is, brand names may be used as indicators of quality (Rao and Monroe, 1989). Such brands tend to be favored by customers who make purchase decisions based on familiarity. Customers learn to predict product quality based on the brand and other cues that are provided via sellers' marketing efforts.

Brand names have been shown to convey quality information to customers, even when quality, per se, has not or even cannot be detected or observed (Rao et al., 1999). Conversely, the absence of a brand name may result in the absence of information about quality. If consumers cannot judge quality prior to purchase and use, then sellers can convey quality using signals via marketing. "A signal is a piece of information that can be revealed to the market at some cost to the provider" (Monroe, 2003, p. 79, emphasis in original). A signal is an observable characteristic (or cue) of the seller or product that may be altered by the seller and may affect consumers' perceptions of quality. For such cues to be perceived as signals there must be (Monroe, 2003, p. 79):

1) Observable differences in the product characteristic or cue across marketers.

2) Differences between marketers with different quality in the cost of providing the cue.

3) Consumers' perceptions of product quality must vary directly with the cue.

\section{Brand Leveraging as Quality Signals}

If a brand name is capable of signaling a level of quality, then the presence of a second brand name could provide an even more powerful signal of quality. On the other hand, if the second brand has an unfavorable image, it may dilute the first brand's image and quality signal. If the second brand is unknown, then the quality assurance must come from the known first brand. Generally, brand leveraging can be used in order to enhance the power of a brand's quality signal by drawing on the signaling power of a second brand (see Figure1.) or, the two brands may augment each brand's quality signal leading to an overall stronger quality assurance (e.g., Dell computers with Intel Inside).

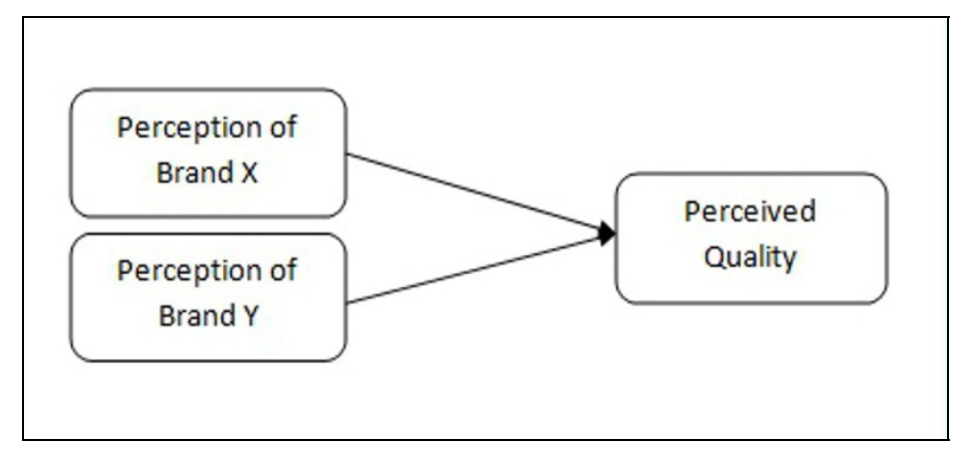

Figure 1. Conceptual model of the effect of brand leveraging on cunsumer's perceived quality in evaluations of product

\section{Effects of Brand Leveraging Strategy on Consumers' Behaviors}

Previous research on the effects of brand Leveraging primarily has addressed issues related to consumers' perceptions of quality of the cobranded product. Researchers have surmised that if perceptions of product quality are enhanced by a brand Leveraging, then consumers would be willing to pay a premium price. Nevertheless this conclusion has not been empirically tested. Indeed, price, even though it is recognized to be a signal of quality, has not been directly included as a variable in previous research on brand Leveraging. Further, if consumers' perceptions of a product's value subsequently influence their willingness to purchase the product, then their 
judgments of value need to be assessed. Consequently, this research will also use the price-quality-value model to study the effect of Brand Leveraging strategy on consumers' perceptions of quality and willingness to buy.

\section{Price-Quality Inferences}

Many consumers use price as an indicator of quality. Image pricing is especially effective with ego-sensitive products such as perfumes and expensive cars.

When alternative information about true quality is available, price becomes a less significant indicator of quality. When this information is not available, price acts as a signal of quality.

Some brands adopt exclusivity and scarcity as a means to signify uniqueness and justify premium pricing. Luxury-goods makers of watches, jewelry, perfume, and other products often emphasize exclusivity in their communication messages and channel strategies. For luxury-goods customers who desire uniqueness, demand may actually increase with higher prices, as they may believe that fewer other customers will be able to afford to purchase the product (Kotler and Keller, 2009).

\section{The Price-Quality-Value Model}

Recognizing that previous co-branding research has not explicitly tested the effect of price on consumers' perceptions of quality, the price-quality-value model is used. In uncertain information environments, price serves both as a signal of perceived monetary sacrifice and as a signal of product quality (Kotler, 1991; Monroe, 2003). Traditionally, price has been considered as a disincentive to purchase products and services, i.e., as a negative product attribute. The price-quality-value model proposes that consumers determine perceived value by mentally trading off or comparing the perceived gains represented in their perceptions of quality or benefits to be received against the perceived loss represented in their perceptions of sacrifice required to acquire the product or service (see Figure2.). In general, judgments of value will increase with increases in perceptions of quality, or decreases in perceptions of sacrifice (Suri and Monroe, 2003). Research has demonstrated that generally brand name is the most influential external cue for assessing quality. That is, the effect of brand name on quality perceptions has been larger than price, store name, or other product characteristics (Monroe, 2003). Understanding that the joint effect of multiple consistently positive cues is stronger than the effects of individual cues is important. It has been shown that although the effect of brand name generally is stronger than price on perceptions of quality. Moreover, the effect of brand name on quality perceptions is stronger in the presence of price information, and conversely, the effect of price on quality perceptions is stronger in the presence of brand name (Monroe and Krishnan, 1985).

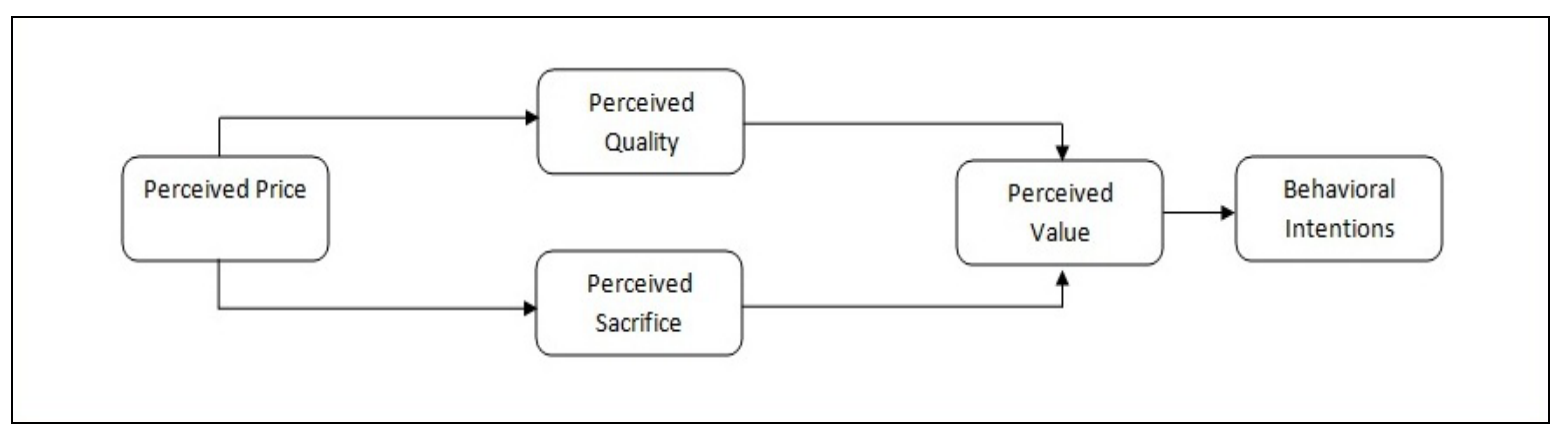

Figure 2. Price-quality-value model

\section{Integrating the Two Conceptual Models}

Earlier, it was argued that using a second brand name with the primary brand would have an interactive effect on consumers' perceptions of quality. Previous research has also shown that brand name and price will have an interaction effect on consumers' perceptions of product quality (Rao and Monroe, 1989; Dodd, Monroe, and Grewal, 1991). Figure 3 presents the entire conceptual model of the impact of price and brand names involved on consumers' evaluations of product and behavioral intentions. 


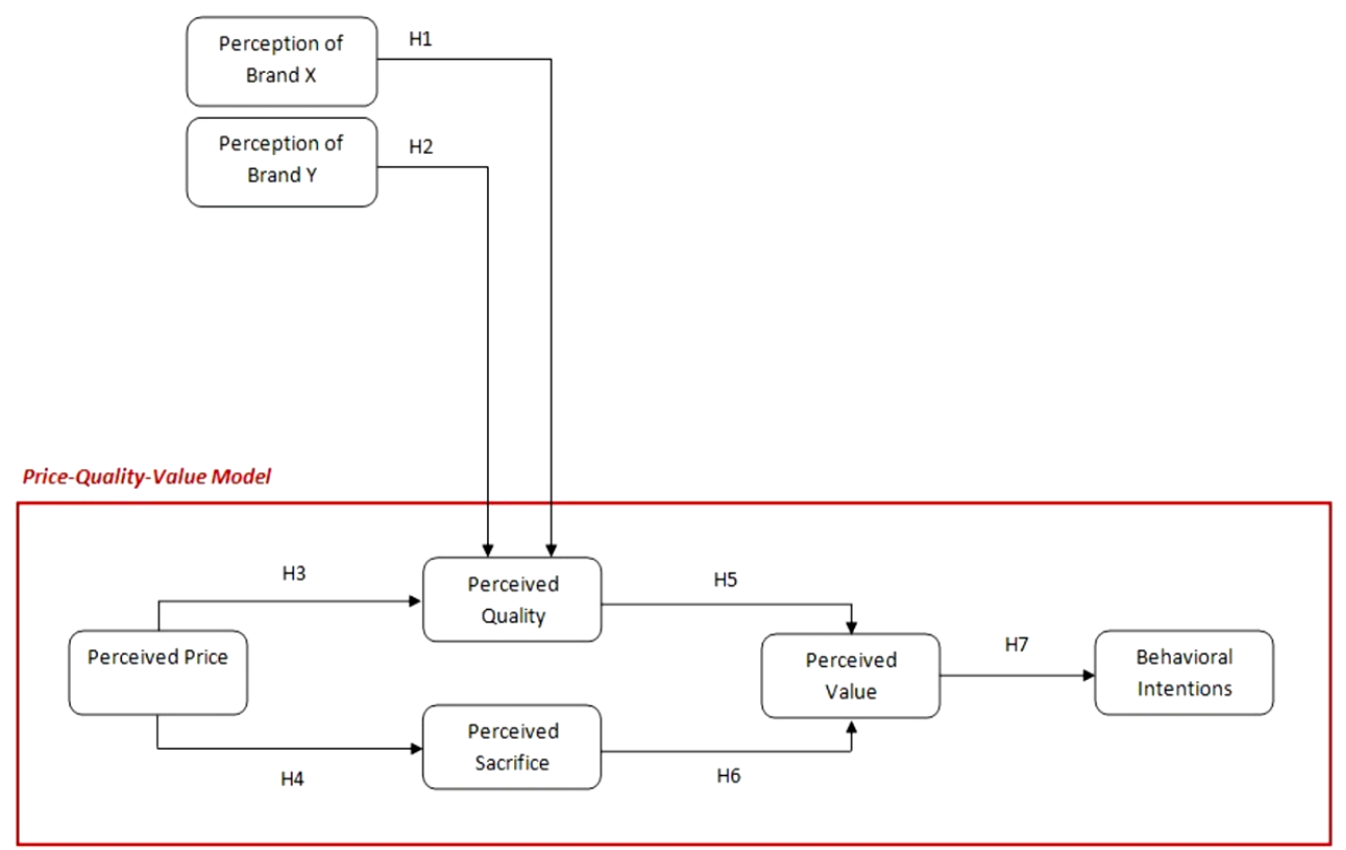

Figure 3. Conceptual model of the effect of brand leveraging and price on consumer's evaluations of product and behavioral intentions

\section{Daily Food Industry}

Dairy industry in Iran with a fifty year old background has more than 400 units of dairy producers all over country. Besides attracting considerable number of labor force in agricultural, industrial, commercial and service sections, dairy industry from point of view of production is considered as one of strategic products that has an especial position in economical and social issues. Thus, this industry was selected for further study. Moreover, in recent years brand leveraging strategy has been used widely in this industry and various products with well known and prominent brand names in Middle East and Europe are produced in Iran that caught consumers' attention.

\section{Background of Research}

Besharat (2010) in his study, "How co-branding versus brand extensions drive consumers' evaluations of new products: A brand equity approach", compares the effectiveness of co-branding versus brand extension strategies and examines whether different levels of brand equity have different effects on consumers' attitudes, quality perceptions, and behavioral intentions for a new product. Results reveal that, partnering with a high-equity brand can derive consumers' evaluations of a new product. However, the findings of comparison indicate that there are no significant differences between co-branding and brand extensions in terms of consumer evaluations of an identical product.

Washburn et al. (2004) in their study, "Brand alliance and customer based brand equity effects" indicated that Co-branding increase positive perception of each brand about their brand equity. Experience attributes are most affected by alliances. Brand names play a role when claims are difficult to evaluate prior to purchase. Lead brand signals quality. The brand partner plays a role in verifying certain product attributes.

Fang and Mishra (2002) in their work, "The effect of brand alliance portfolio on the perceived quality of an unknown brand" showed that the perception of an unknown brand with high quality partners is higher than that of the brand with a combination of high and low quality partners. If the high quality partners come from different product categories, the quality perception of unknown brand will be greatly enhanced.

Levin and Levin (2000) in their study, "Modeling the role of brand alliances in the assimilation of product evaluations" find that when two brands are linked through a dual-branding arrangement and both brands are described by the same set of attributes, then the effect of dual branding is to reduce or eliminate contrast effects. When two brands are linked through a dual-branding arrangement and the target brand is less well specified than the context brand, then the effect of dual branding is to increase assimilation effects. 


\section{Methodology}

\subsection{Pretest: Selection of Brand Names}

To determine the appropriate brand names a pretest was conducted. Three companies are working in Iran to producing dessert: Kalleh, Ramak and Danone Sahar (Danette). The first part of the pretest was to measure the degree of familiarity of these brand names and the second part was designed to measure the degree of quality of these. The participants $(\mathrm{n}=30)$ whose characteristics were similar to those that would be participating in the main study were instructed to indicate the extent to which they are familiar with the brand names through a series of 5-point likert scales (1="Unfamiliar", 5="Highly familiar") in the first section. Similarly, for the second, they were asked to evaluate the quality of each brand name on a 5-point likert scale (1="Low quality", $5=$ ="High quality").

Through this procedure the perceived quality point of view Danette's Pudding with the highest mean and Ramak's pudding with the lowest mean were selected (Danette's pudding: Mean $=4.4333$, Std.Deviation=0.62606; Ramak's pudding: Mean=2.9667, Std.Deviation=0.76489). From the aspect of familiarity Kalleh's pudding has the highest mean, and then respectively Danette's pudding and Ramak's pudding are next (Kalleh's pudding: Mean=4.5667, Std.Deviation=0.56832; Danette's pudding: Mean=4.0333, Std.Deviation=0.61495; Ramak's pudding: Mean=3.0333, Std.Deviation=0.76489). However, regarding the fact that the purpose of this study is to investigate the impact of brand leveraging strategy on consumer's purchase intention, Danette's puddings (since, Danon Sahar Co. utilizes brand leveraging strategy in introducing its new puddings to the market) and Ramak's puddings are selected.

\subsection{Main Study}

This study can be considered as an applied research from purpose perspective and descriptive-survey with regards to the nature and method (type of correlation). A self administered questionnaire designed by researchers used to collect required data in order to support or reject hypotheses. All questions were on 5-point likert scale $(1=$ "Strongly disagree" and 5="Strongly agree"). The purpose of this study is investigation effects of price and brand leveraging strategy, both, on Consumer's behavioral Intention. This goal has been followed by examining the impact of perception of brand names involved on perceived quality and understanding relationships between relative price, perceived quality, perceived sacrifice, perceived value and willingness to buy base on price-quality-value model as the hypotheses of the study. This study was conducted among 136 shoppers (female: $54.4 \%$ and male: $45.6 \%$ ) at several cooperative companies in Isfahan city, Iran (see Table 1.). Also, this study was done from August, 2011 to August, 2012.

Independent variables in this study are as follows:

- Perception of brand X (Danone Sahar)

- Perception of brand Y (Danette)

- Perception of brand Z (Ramak)

- Perceived price

- The degree of familiarity with brand Names

And study's dependent variables are:

- Perceived quality

- Perceived sacrifice

- Perceived value

- Behavioral Intentions

Table 1. Demographic profile of participants $(n=136)$

\begin{tabular}{lcc}
\hline Variables & Frequency & Percentage \\
\hline Age & 6 & \\
Lower than 18 & 57 & 4.4 \\
$19-30$ & 51 & 41.9 \\
$31-45$ & 37.5 \\
\hline
\end{tabular}




\begin{tabular}{lcc}
\hline $46-60$ & 18 & 13.2 \\
Upper than 60 & 4 & 3 \\
Income & & \\
Lower than 300,000 Toman & 34 & 25 \\
300,000-500,000 Toman & 47 & 34.6 \\
$500,000-800,000$ Toman & 18 & 13.2 \\
Upper than 800,000 Toman & 37 & 27.2 \\
\hline
\end{tabular}

\section{Data Analysis and Results}

SPSS 19 was used for basic statistical analysis, factor analysis and reliability analysis, and AMOS was adopted for analysis of the structural equation model (SME). To test the conceptual model of the effect of brand leveraging and price on consumer's evaluations of product and behavioral intentions (see Figure3.), a structural equation modeling technique was used.

In order to test the study's first hypothesis a linear regressions were used to analyse the relationships between the degree of familiarity with brand Names (independent variables) and the perceived quality (dependent variables). For testing the other study's hypotheses structural equation model and path analysis were used to analyse the relationships between variables. The hypotheses and results are as follows:

H1: The degree of consumer's familiarity with the brand names affects their perception of perceived quality.

The degree of consumer's familiarity of brand names, brand $A$ and brand $B$, were significant at the 0.05 level (see Table1\&2.). Thus, $H 1$ is fully supported.

$$
\begin{aligned}
& y=2.919+0.176 x \\
& y=\text { Perceived quality } \\
& x=\text { The degree of consumer's familiarity with the brand A (Danette) }
\end{aligned}
$$

Table 2. Regressions of the degree of consumer's familiarity with the brand A and perceived quality

\begin{tabular}{lcccc}
\hline Unstandardized Coefficients & \multicolumn{2}{c}{ Standardized Coefficients } & \multirow{2}{*}{ Sig. } & Durbin-Watson \\
\cline { 1 - 3 } & $\beta$ & Beta & & \\
\cline { 1 - 2 } $\begin{array}{l}\text { Constant } \\
\begin{array}{l}\text { The degree of consumer's familiarity } \\
\text { with the brand names }\end{array}\end{array}$ & 0.176 & 0.312 & 0.000 & 1.873 \\
\cline { 1 - 2 } & & & & \\
\hline
\end{tabular}

Notes: ${ }^{* *}$ Denotes significance at the 0.05 level

$$
\begin{aligned}
& y=2.125+0.240 x \\
& y=\text { Perceived quality } \\
& x=\text { The degree of consumer's familiarity with the brand B (Ramak) }
\end{aligned}
$$

Table 3. Regressions of the degree of consumer's familiarity with the brand B and perceived quality

\begin{tabular}{lllll}
\hline Unstandardized Coefficients & \multicolumn{2}{l}{ Standardized Coefficients } & Sig. & \multirow{2}{*}{ Durbin-Watson } \\
\cline { 1 - 4 } & $\beta$ & Beta & & \\
\hline Constant & 2.125 & 0.295 & 0.000 & 1.520 \\
$\begin{array}{l}\text { The degree of consumer's familiarity } \\
\text { with the brand names }\end{array}$ & 0.240 & & & \\
\end{tabular}

Notes: ${ }^{* *}$ Denotes significance at the 0.05 level 
As the table (2) indicates, the Beta (0.319) of the degree of consumer's familiarity with the Danette Regressions is higher than the Beta $(0.295)$ of The degree of consumer's familiarity with the Ramak Regressions.

H2: Using of brand leveraging strategy (using a credible and familiar brand's logo and name with the unfamiliar brand name on the product) affects the consumer's perception of perceived quality.

H3: Consumer's perception of price positively affects their perception of perceived quality.

H4: Consumer's perception of price positively affects their perception of perceived sacrifice.

H5: Consumer's perception of quality positively affects their perception of value.

H6: Consumer's perception of perceived sacrifice negatively affects their perceptions of value.

H7: Consumer's perceptions of value positively affect their purchase intentions.

To test the other proposed hypotheses, data were collected and analyzed using structural equation modeling supported by AMOS with maximum likelihood estimation. SEM is a second generation multivariate technique that combines multiple regressions with confirmatory factor analysis to estimate a series of interrelated dependence relationships simultaneously. SEM is a widespread technique in several fields including marketing, psychology, social sciences and information systems. Hence, the structural equation model is applied to validate the relationship among variables in the research model. This study applies Amos to perform data analyses. The measurement model is used to test the validity and reliability of items and constructs in the research model.

The steps described in the last section reduced the data and resulted in a manageable number of valid and more reliable measurement items which were then used to evaluate the structural model in this section. The overall fit indices for the proposed structural model were, $\mathrm{x} 2$ /df ratio of 1.827 for Danette and 2.350 for Ramak, a CFI of 0.964 for Danette and 0.978 for Ramak and the RMSEA of 0.078 for Danette and 0.080 for Ramak. These values indicated that the model fits the data well. Having established the final structural equation model, it was possible to test the hypotheses developed for this study. These hypotheses can be tested by evaluating the path coefficients and the significance levels among the constructs in the model.

Table 4. Fit indices for the measurement (Danette)

\begin{tabular}{lcc}
\hline Fit indicators & Criteria & Structural model \\
\hline $\mathrm{X} \mathrm{2/d} f$ & $<3$ & 1.827 \\
GFI & $>0.9$ & 0.964 \\
AGFI & $>0.8$ & 0.900 \\
NFI & $>0.9$ & 0.967 \\
CFI & $>0.9$ & 0.985 \\
IFI & $>0.9$ & 0.984 \\
RMSEA & $<=0.0 .8$ & 0.078 \\
RMR & $<0.05$ & 0.040 \\
\hline
\end{tabular}

Table 5. Fit indices for the measurement (Ramak)

\begin{tabular}{lcc}
\hline Fit indicators & Criteria & Structural model \\
\hline $\mathrm{X} 2 / \mathrm{d} f$ & $<3$ & 2.350 \\
$\mathrm{GFI}$ & $>0.9$ & 0.978 \\
$\mathrm{AGFI}$ & $>0.8$ & 0.982 \\
$\mathrm{NFI}$ & $>0.9$ & 0.984 \\
$\mathrm{CFI}$ & $>0.9$ & 0.991 \\
$\mathrm{IFI}$ & $>0.9$ & 0.991 \\
RMSEA & $<=0.0 .8$ & 0.080 \\
RMR & $<0.05$ & 0.039 \\
\hline
\end{tabular}


Figure 4 and 5 presents the results standardized path coefficients between the proposed constructs. Comparing 0.57 percent in Danette model with 0.43 percent in Ramak Model indicated that customer's behavioral intention was significantly influenced by brand leveraging.

The results support all the hypotheses: The degree of consumer's familiarity with the brand effect (H1), brand effect $(\mathrm{H} 2)$, price effect on perceived quality (H3), perceived price and perceived sacrifice (H4), perceived quality and perceived value (H5), perceived sacrifice and perceived value (H6) and perceived value and willingness to buy (H8). Utilization of brand leveraging strategy affects the consumer's perception of perceived quality (attention to $0.53,-0.1$ and 0.38 percent in models). Consumer's perception of price positively affects their perception of perceived quality (attention to 0.12 and 0.32 percent in models). Consumer's perception of price positively affects their perception of perceived sacrifice (attention to 0.91 and 0.90 percent in models) .Consumer's perception of quality positively affects their perception of value (attention to 0.45 and 0.44 percent in models). Consumer's perception of perceived sacrifice negatively affects their perceptions of value (attention to -0.46 and -0.32 percent in models). Consumer's perceptions of value positively affect their purchase intentions (attention to 0.57 and 0.43 percent in models).

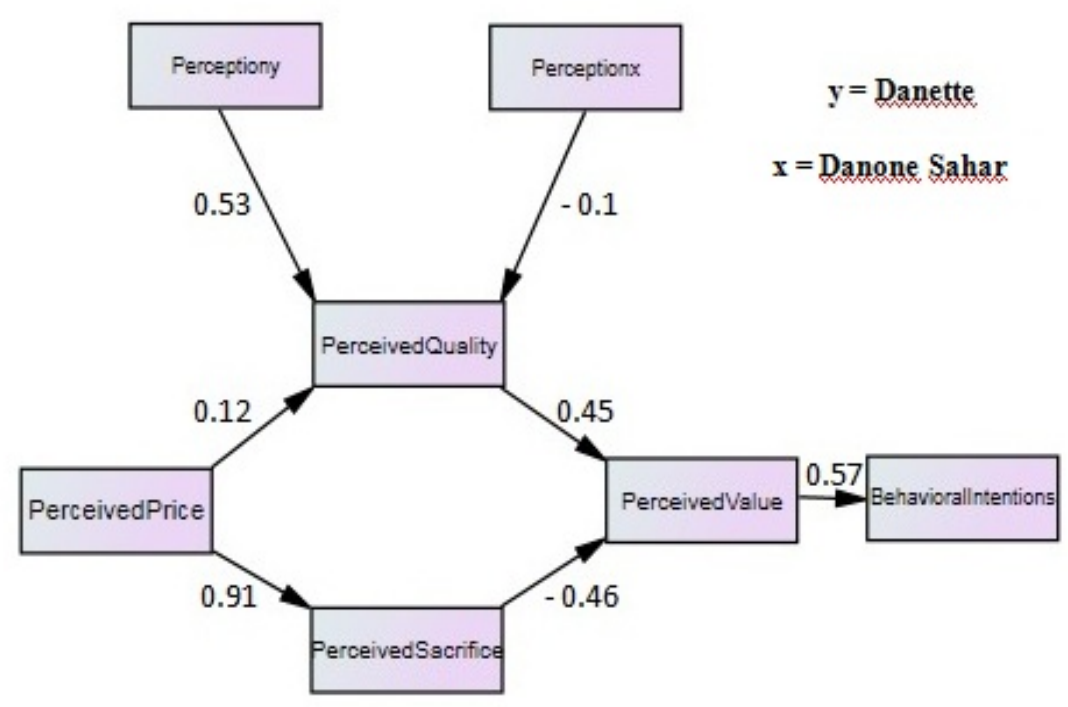

Figure 4. Conceptual model of the effect of brand leveraging and price on consumer's evaluations of product and behavioral intentions for danette

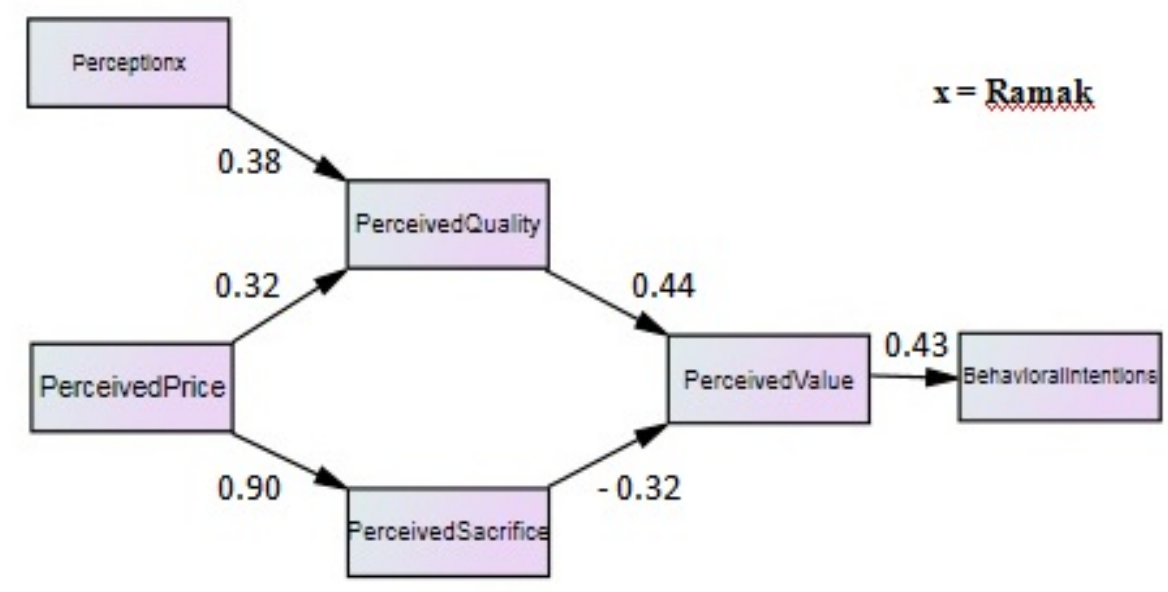

Figure 5. Conceptual model of the effect of brand leveraging and price on consumer's evaluations of product and behavioral intentions for ramak 


\section{Conclusion}

The use of brand leveraging strategy may influence consumers' judgments of the product quality and their purchase intentions.

By definition, brand leveraging or co-branding are marketing activities that involve short or long term associations or combinations of two or more brands on the products that are presented jointly to the consumers (Rao and Ruekert, 1994). Cobranded products are likely to be evaluated more favorably than single brand products (Park and Shocker, 1996). Having a credible and familiar brand name on the product may signal the credibility of the quality claims and information on certain product attributes to consumers.

The definition of brand leveraging is built upon the signaling theory paradigm in marketing, when there is an unobservable quality, marketing signals such as brand, price, advertising expenditure, and warranties can be implemented to inform consumers about the unobservable quality of the products.

Besides extending knowledge from the signaling and information integration paradigm, this research bridges the gap between branding and pricing in marketing literatures. This knowledge provides the conceptual foundation for understanding how the usage of brand leveraging on products influences consumers' evaluations of quality and their willingness to buy the products. Conceptual Model of the effect of brand leveraging and price on consumer's evaluations of product and behavioral intentions was developed and tested in this research. Using the price-value-quality model to link the three independent variables, primary brand, second brand and price, with the consumer's perception of product quality and their willingness to buy the product. In uncertain information environments, price serves both as a signal of perceived monetary sacrifice and as a signal of product quality, so in all the circumstances, high prices are not signs of better quality for consumers.

Our findings are consistent with the findings from the previous studies (Keller, 2003, 1991; Monroe, 2003; Suri and Monroe, 2003; Van Osselaer and Alba, 2000; Urbany et al., 1996; Rao et al., 1999; Kotler, 1991; Rao and Monroe, 1989).

\section{Managerial Implications}

This research makes a significant contribution to answer managerial questions such as how the branding and pricing strategy should be selected and implemented. This dissertation research concluded that a brand leveraging strategy affects consumers' evaluations of product quality.

Since there is a cost up front for marketers in branding, the benefits from enhancing quality perceptions can be realized by choosing the appropriate marketing mix strategy and examining the role of competitive products in the market. The key finding in this research is that all the signals (brand names involved and price) must be consistent. The findings demonstrated that all positive signals or cues when all together may create the greatest enhancement of quality perceptions. In the situation when other products in the market are co-branded, setting the price low and not using of co-branding may dilute quality perceptions of the products. The perception of quality may be diluted more for an unfamiliar brand than for a familiar one.

When alternative information about true quality is available, price becomes a less significant indicator of quality. When this information is not available, price acts as a signal of quality (Kotler and Keller, 2009).

\section{Reference}

Ajit K., \& Melinda Smith-de B. (1996). Transaction Utility Effects When Quality is Uncertain. Journal of the Academy of Marketing Science, 25(1), 45-55. http://dx.doi.org/10.1177/0092070397251005

Dodds, William B., Kent B. M., \& Dhruv G. (1991). Effects of Price, Brand, and Store Information on Consumers' Product Evaluations. Journal of Marketing Research, 28(3), 307-19. http://dx.doi.org/10.2307/3172866

John, Deborah R., Barbara L., \& Christopher J. (1998). The Negative Impact of Extendions: Can Flagship Products be Diluted? Journal of Marketing, 62(1), 19-32. http://dx.doi.org/10.2307/1251800

Keller, Kevin L. (2003). Brand Synthesis: The Multidimensionality of Brand Knowledge. Journal of Consumer Research, 29(4), 595-600. http://dx.doi.org/10.1086/346254

Kent B. M. (1989). The Effect of Price, Brand Name, and Store Name on Consumers' Perceptions of Quality. Journal of Marketing Research, 26(3), 351-57. http://dx.doi.org/10.2307/3172907

Kirmani, A., \& Akshay R. (2000). No pain, No Gain: A Critical Review of the Literature on Signaling Unobservable Product $\quad$ Quality. Journal of Marketing, 64(2), 66-79. 
http://dx.doi.org/10.1509/jmkg.64.2.66.18000

Kotler, P. (1991). Marketing Management (7th ed.). Englewood Cliffs, NJ: Prentice-Hall, Inc.

Kotler, P., \& Keller, Kevin L. (2009). Marketing Management (13th ed.). Englewood Cliffs, NJ: Prentice-Hall, Inc.

Laric, Michael V., \& Dan S. (1981). Consumer (Mis) Perceptions and Usage of Third Party Certification Marks, 1972 and 1980: Did Public Policy Have an Impact? Journal of Marketing, 45(3), 135-42. http://dx.doi.org/10.2307/1251548

Levin, Irwin P., \& Aron M. L. (2000). Modeling the Role of Brand Alliances in the Assimilation of Product Evaluations. Journal of Consumer Psychology, 9(1), 43-52. http://dx.doi.org/10.1207/s15327663jcp0901_4

Monroe, K. B. (2003). Pricing: Making Profitable Decisions (3rd ed.). Boston, MA: McGraw-Hill/Irwin.

Park, C. W., Sung Youl J., \& Allan D. S. (1996). Composite Branding Alliances: An Investigation of Extension and Feedback Effects. Journal of Marketing Research, 33(4), 453-66. http://dx.doi.org/10.2307/3152216

Phelps, D. M. (1949). Certification Marks under the Lanham Act. Journal of Marketing, 13(4), 498-505. http://dx.doi.org/10.2307/1247789

Ram K. (1985). The Effect of Price on Subjective Product Evaluation. In Jacob J., \& Jerry C. O. (eds.), Perceived Quality: How Consumers View Stores and Merchandise (pp. 209-32). Lexington, MA: Lexington Books.

Rao, Akshay R., Lu Q., \& Robert W. R. (1999). Signaling Unobservable Product Quality through a Brand Ally. Journal of Marketing Research, 36(2), 258-68. http://dx.doi.org/10.2307/3152097

Robert W. R. (1994). Brand Alliances as Signals of Product Quality. Sloan Management Review, 36(1), 87-97.

Rodrigue, Christina S., \& Abhijit B. (2004). Brand Alliance Dependency and Exclusivity: an Empirical Investigation. The Journal of Product and Brand Management, 13(7), 477-88. http://dx.doi.org/10.1108/10610420410568417

Simonin, Bernard L., \& Julie A. R. (1995). Bundling as a Strategy for New Product Introduction: Effects on Consumers' Reservation Prices for the Bundle, the New Product, and Its Tie-in. Journal of Business Research, 33(3), 219-30. http://dx.doi.org/10.1016/0148-2963(94)00071-L

Suri, R., \& Kent B. M. (2003). The Effect of Time Constraints on Consumers' Judgments of Prices and Products. Journal of Consumer Research, 30(1), 39-46. http://dx.doi.org/10.1086/374696

Urbany, Joel E., William O. B., \& Dan C. W. (1988). Plausible and Exaggerated Reference Prices: Effects on Perceptions and Price Search. Journal of Consumer Research, 15(June), 95-110. http://dx.doi.org/10.1086/209148

Van O., Stijn M. J., \& Joseph W. A. (2000). Consumer Learning and Brand Equity. Journal of Consumer Research, 27(1), 1-16. http://dx.doi.org/10.1086/314305 